\title{
Effect of anthropogenic disturbance on the abundance and habitat occupancy of two endemic hornbill species in Buton island, Sulawesi
}

\author{
NURUL L. WINARNI and MARTIN JONES
}

\section{Summary}

The Red-knobbed Hornbill Rhyticeros cassidix and the Sulawesi Tarictic Hornbill Penelopides exarhatus are endemic to Sulawesi. This study assessed the effect of anthropogenic disturbance on these two species in Lambusango forest, Buton, south-east Sulawesi. Data were collected between 2005 and 2007 in six study sites which varied in their levels of disturbance. Two of the lightly disturbed and two of the more heavily disturbed sites were within 'protection forest' whereas the rest were classified as 'production forest'. We used point counts with distance sampling to survey the hornbills. Habitat data were also collected at each of the points and related to hornbill 'occupancy' with the program PRESENCE. Both hornbills were estimated to be at higher density in the lightly disturbed forest but the level of disturbance had more of a detrimental effect on Red-knobbed Hornbill than on Sulawesi Tarictic Hornbill. Lightly disturbed forest had significantly more large trees than the heavily disturbed forest but there was no difference in the abundance of figs. Using four covariates (disturbance level, protection status, number of large trees, and number of figs), $99 \%$ of presence/absence of Red-knobbed Hornbills at the points could be explained by habitat disturbance and $87 \%$ by forest status; the same covariates explained $76 \%$ of presence/absence for the Sulawesi Tarictic Hornbill with abundance of large trees as the most important factor. These results support the notion that Red-knobbed Hornbill is more sensitive to anthropogenic disturbance and its conservation is highly dependent upon the preservation of forest habitats with low levels of disturbance.

\section{Introduction}

Sulawesi and its associated islands are located in Wallacea and support a combination of Oriental and Australasian biotas; levels of endemism are high in comparison to other islands in Indonesia ( $\mathrm{O}^{\prime}$ Brien and Kinnaird 2000, Whitten et al. 2002). At least 280 bird species are recorded and ${ }^{1} \mathrm{I}$ (14.6\%) species and 17 genera are endemic (Coates et al. 1997, Whitten et al. 2002). There are two endemic hornbills, Red-knobbed Hornbill Rhyticeros cassidix and Sulawesi Tarictic Hornbill Penelopides exarhatus (Coates et al. 1997) which are thought to be dependent on forest below $2,000 \mathrm{~m}$ asl (Kinnaird and O'Brien 2007). Sulawesi is mostly mountainous with only $25 \%$ of its area classified as lowlands (Holmes 2002). Between 1985 and 1997, Sulawesi suffered an $89 \%$ loss of lowland forest because of commercial logging, transmigration, and estate crop plantation (FWI/GFW 2002). This is one of the highest rates of deforestation amongst all of the larger islands in Indonesia (FWI/GFW 2002). The influx of migrants has caused additional pressure on the forest through the increase in illegal logging and agricultural encroachment (Whitten et al. 2002). 
Buton Island, with Lambusango forest at its centre, lies in the south-eastern part of Sulawesi. The forest covers approximately 35,000 ha, and supports a high level of animal biodiversity including Lowland Anoa Bubalus depressicornis and Buton Macaque Macaca ochreata brunnescens. Because of the proximity to many settlements, including Buton's largest town Bau-bau, Lambusango forest is subjected to different forms of anthropogenic pressures such as agricultural encroachment, uncontrolled harvesting of non-timber forest products (NTFP), as well as bushmeat hunting and asphalt mining (Singer and Purwanto 2006).

Within Sulawesi, the Red-knobbed Hornbill is usually more abundant than the Sulawesi Tarictic Hornbill and has a larger home range (Kinnaird and O'Brien 2005). Both species have high proportions of fruit in their diet, although the Red-knobbed Hornbill is more dependent on figs (Kinnaird and O'Brien 2005, Walker 2007). As with other hornbill species, because of their large size and specific diet, they could be considered as umbrella species and indicators of forest health. They are also able to move between forest patches and, as seed dispersers, they may have an important role in forest regeneration (Whitney and Smith 1998).

The response of hornbill species to disturbance is varied. Whitney and Smith (1998) found that the African Ceratogymna hornbill species were reliant on the continued presence of particular nesting trees (Kalina 1988) and Marsden and Jones (1997) indicated something similar for the Sumba Hornbill. Several studies have suggested that many hornbill species' abundance is affected by logging because of the paucity of fruiting trees (Anggraini et al. 2000, Cleary et al. 2007). A previous study of the Red-knobbed Hornbill suggests that it avoids secondary forest and agroforest (Waltert et al. 2004) but there has been no proper evaluation of the response of either species to different levels of disturbance. Therefore, in this study we evaluate the effect of disturbance on the occupancy patterns and the abundance of these insular hornbill populations and aim to identify the habitat features that are associated with hornbill occupancy.

\section{Study area and Methods}

\section{Study area}

This study was carried out in Lambusango forest during 2005-2007. The forest $\left(5^{\circ} \mathrm{O} 9^{\prime}-5^{\circ} 24^{\prime} \mathrm{S}\right.$, $122^{\circ} 43^{\prime}-23^{\circ} \mathrm{O} 7^{\prime} \mathrm{E}$ ) lies in the centre of Buton island, south-east Sulawesi, Indonesia at an elevation of $50-780 \mathrm{~m}$ asl (Singer and Purwanto 2006). The 35,000 ha forest covers protected areas (combining wildlife reserve and nature reserve) as well as production and protection forests (Figure 1). At least 95 forest bird species have been recorded, with $37 \%$ endemic to Sulawesi (Singer and Purwanto 2006).

There were six study sites evenly distributed within Lambusango, four situated in forest reserves (Anoa, Lapago, Wahalaka, and Wabalamba) and two in the limited production forest (Lawele and Lasolo) which are forests allocated for low-intensity timber production (FWI/GFW 2002) (Figure 1). Two disturbance levels characterise the Lambusango forest; Anoa, Lapago, and Lawele in the northern part are considered to be less disturbed, and Lasolo, Wabalamba and Wahalaka in the southern part, more heavily disturbed (Seymour 2004, Winarni 2009, Winarni and Jones 2009). This distinction was based on differences in the structure of the dominant vegetation (Figure 1): the lightly disturbed habitats supported more Pandanus spp., palms, lianas, ferns; the more heavily disturbed habitats showed the opposite and also had higher canopy openness and more fallen trees (Winarni 2009, Winarni and Jones 2009).

\section{Hornbill survey}

As part of the general Lambusango Forest Conservation Project, hornbills were surveyed using the Variable Circular Plot method (point counts with distance estimates to each contact) following Reynolds et al. (1980) and Jones et al. (1995) at the six study sites. Surveys were conducted in the dry season (July-August) in 2005 and in the dry and wet seasons (May-June) in 2006 and 2007. 


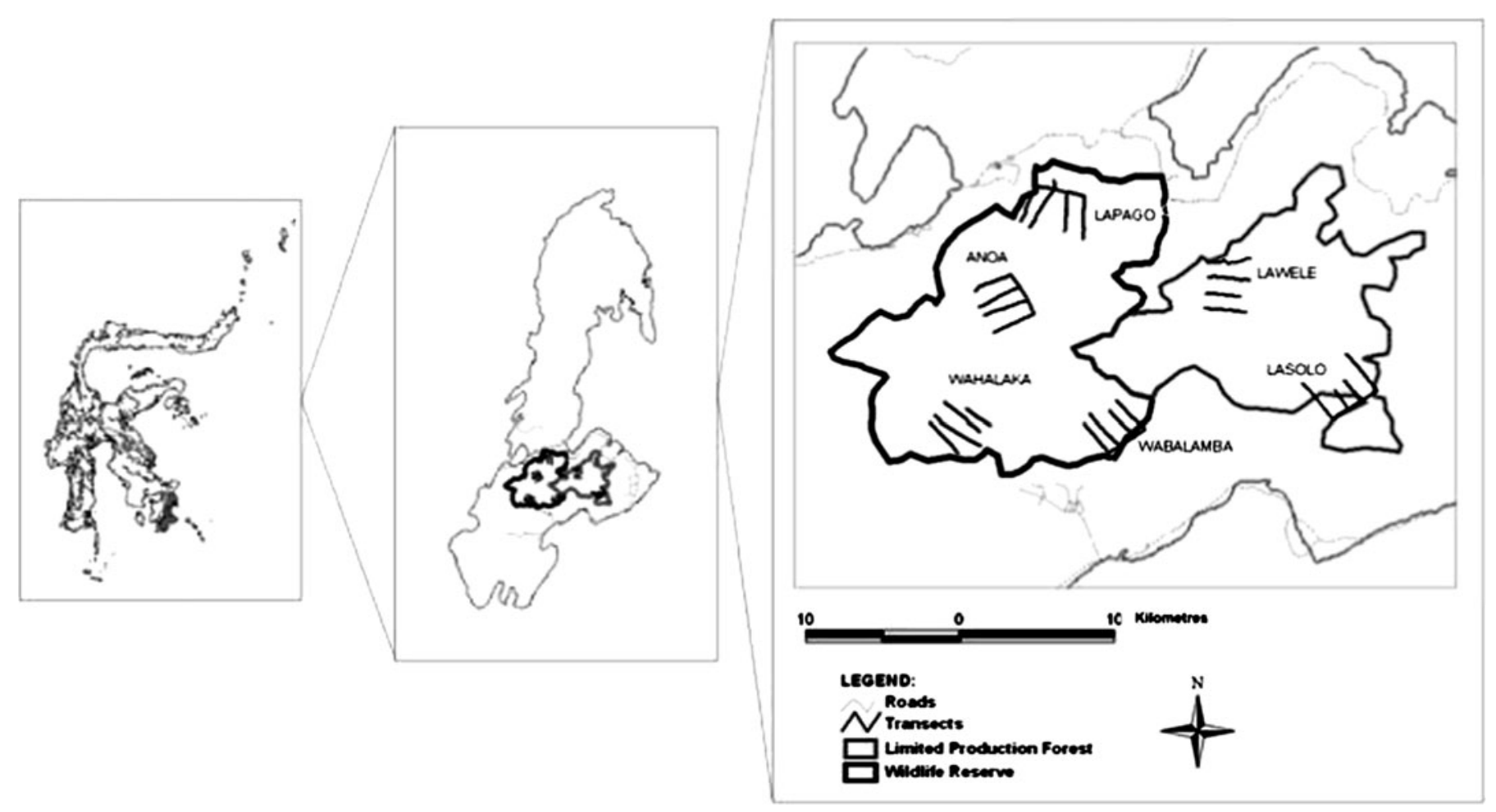

5
$\vdots$
3
3
3
3
3
$\vdots$
$\vdots$
3
0
0
0
0

Figure 1. The forest of Lambusango relative to Buton island and Sulawesi, and the distribution of study sites. 
The survey in 2005 excluded the newly set-up transects in Lasolo. The number of actual sampling days is presented in Table 1 .

The placement of points was not random because of problems of accessibility; they were laid out on four transects of $3 \mathrm{~km}$ length at each study site. The distance between transects was $1 \mathrm{~km}$ and each transect was marked at $50 \mathrm{~m}$ intervals. Points were located at $150 \mathrm{~m}$ intervals along each of the four transects at each study sites up to $900 \mathrm{~m}$ and were visited between 06 hoo and o8hoo. Preliminary surveys in the area suggested that bird activity (including that of hornbills) started to increase at 06 hoo and dropped off markedly after o8hoo hours. Therefore we decided to use a 150-m interval between adjacent points to reduce the travelling distance between each point and increase the number of points each day (Winarni 2009). Positions of individuals at a point were noted to avoid double counting.

There were two groups of recorders, each of 2-3 people, who stayed at each point and recorded any birds detected around the central point for 10 minutes without the use of a settling down period (Lee and Marsden 2008). Each group visited different points each day and made counts only once at each point. When one group conducted a count at one point, then the other group would replicate the point on the following day. A single survey visit with replication resulted in 28 point count stations at each study site or 168 point count stations in total. All hornbills heard and seen were recorded and an estimate of distance was made to each contact. Flying birds were excluded. One week prior to survey, all observers were trained in bird identification and distance estimation.

\section{Habitat assessment}

We used the same point count stations to count figs and large trees. These variables were quantified within a $20 \mathrm{~m}$ radius circular area around the points. Figs were defined as any strangling figs, and large trees were defined as any trees with diameter at breast height $(\mathrm{DBH})>50 \mathrm{~cm}$ within the area. Mann-Whitney U-tests were used to compare the densities of large trees and figs between the two disturbance levels because the densities were not normally distributed and not easily transformed.

\section{Density analysis}

DISTANCE 5.o (Thomas et al. 2006) was used to estimate the densities of the two hornbill species in each habitat category, the less heavily (Anoa, Lapago, and Lawele) and more heavily (Lasolo, Wabalamba and Wahalaka) disturbed forests (Buckland et al. 2001). For this analysis, all data from different observers, different seasons, and from the two disturbance levels during 20052007 were pooled and then post-stratified to obtain density estimates for less disturbed and more disturbed habitats (Marsden et al. 2001). This provides larger sample sizes and so increases precision (Marsden 1999). Distances over $100 \mathrm{~m}$ were truncated because they comprised only

Table 1 . Number of actual sampling days at each study site per year.

\begin{tabular}{|c|c|c|c|c|}
\hline & \multicolumn{3}{|c|}{ Number of days surveyed } & \multirow[t]{2}{*}{ Total } \\
\hline & 2005 & 2006 & 2007 & \\
\hline \multicolumn{5}{|c|}{ Lightly disturbed habitats } \\
\hline Anoa & 4 & 8 & 4 & 16 \\
\hline Lapago & 4 & 6 & 4 & 14 \\
\hline Lawele & 4 & 8 & 12 & 24 \\
\hline \multicolumn{5}{|c|}{ Heavily disturbed habitats } \\
\hline Lasolo & $\mathrm{O}$ & 8 & 14 & 22 \\
\hline Wabalamba & 4 & 7 & 8 & 19 \\
\hline Wahalaka & 4 & 7 & 1 & 12 \\
\hline
\end{tabular}


$0.9 \%$ of the observations and they can adversely affect the modeling of the detection function within Distance (Buckland et al. 2001). Three detection functions were fitted - half-normal, uniform, and hazard rate. The best fit was selected based on the minimum AIC (Akaike's Information Criterion) provided by the program (Buckland et al. 2001). Differences in density estimates between lightly disturbed $\left(\bar{D}_{0}\right)$ and heavily disturbed sites $\left(\bar{D}_{1}\right)$ were tested using $Z$ tests as described in Buckland et al. (2001).

\section{Occupancy analysis}

The program PRESENCE vers 2.2 (MacKenzie et al. 2002, MacKenzie et al. 2006) was used to model the habitat factors associated with the presence/absence of hornbills at each point station in the study sites per year. This is a likelihood-based method which estimates the proportion of area occupied when detections are varied (MacKenzie et al. 2006). Single species, multi-season analyses were used with four covariates - degree of disturbance (light or heavy), forest status (protected or production), number of large trees, and number of figs. Considering that hornbills are easily detected by calls and appearance, we assumed that the species was identified correctly, the detection probability $(p)$ was constant over time, and over different disturbance levels (Hadiprakarsa 2008) and we also assumed that occupancy $(\Psi)$ is affected by different covariates but not over time. Models used were each of the four covariates and combination of covariates, creating 15 different models for each species. Akaike's Information Criterion (AIC) was used to rank the candidate models in the model selection. AIC is defined as $-2 \ln (L)+2 k$ where $L$ is likelihood and $k$ is the number of parameters (Burnham and Anderson 2004). In this study, we used the models selected to make inferences on habitat selection of the two hornbill species (MacKenzie et al. 2006). In addition to using the lowest AIC values to select the most parsimonious model, we also summed the AIC weight $(w)$ for each covariate used in all models to select which covariate was the best of the habitat association of each hornbill species. Covariates used in the highest ranked models will give larger total AIC weights than those which appear in the lowest ranked (Burnham and Anderson 2004, MacKenzie et al. 2006).

\section{Results}

\section{Variations of tree and fig abundance between study sites}

The lightly disturbed habitats had significantly more large trees than the heavily disturbed habitats (lightly disturbed $\bar{x}=4.73 \pm 0.28 \mathrm{SE}$; heavily disturbed $\bar{x}=3.74 \pm 0.27 \mathrm{SE}$; Mann-Whitney $U=$ 2642.0, $Z=-2.612 ; P<0.001$ ). Amongst the study sites, distribution of large trees was more variable. Lawele, a lightly disturbed habitat $(\bar{x}=5.96 \pm 0.44 \mathrm{SE})$ had the most large trees followed by Lasolo $(\bar{x}=5.36 \pm 0.42 \mathrm{SE})$ and then Wahalaka $(\bar{x}=2.71 \pm 0.47 \mathrm{SE}$ ) (Figure 2). Fig abundance, however, was not different between the two disturbance levels (lightly disturbed $\bar{x}=0.24 \pm 0.06 \mathrm{SE}$; heavily disturbed $\bar{x}=0.36 \pm 0.10 \mathrm{SE}$; Mann-Whitney $U=3472.0 ; \mathrm{Z}=$ -0.257; $P=0.80)$. Wabalamba $(\bar{x}=0.50 \pm 0.24 \mathrm{SE})$, the heavily disturbed habitat, had most figs whereas Anoa, one of the lightly disturbed habitats $(\bar{x}=0.14 \pm 0.07 \mathrm{SE})$ had the fewest (Figure 2 ).

\section{Hornbill abundance}

In total, 614 observations were recorded for the two hornbill species during 2005-2007 (Redknobbed Hornbill $=236$ observations, Sulawesi Tarictic Hornbill $=378$ observations, 956 birds in total. Red-knobbed Hornbills were recorded at 75 points across all study sites whereas Sulawesi Tarictic Hornbills were recorded at 116 points. Number of observations for Sulawesi Tarictic Hornbill was higher than for Red-knobbed Hornbill at all sites except Lapago and Lawele (Table 2). More hornbills were seen in the lightly disturbed forest (Table 2) but the difference was only significant for Red-knobbed Hornbill (Red-knobbed Hornbill $U=1716.0, Z=-6.33, P<0.05$; 


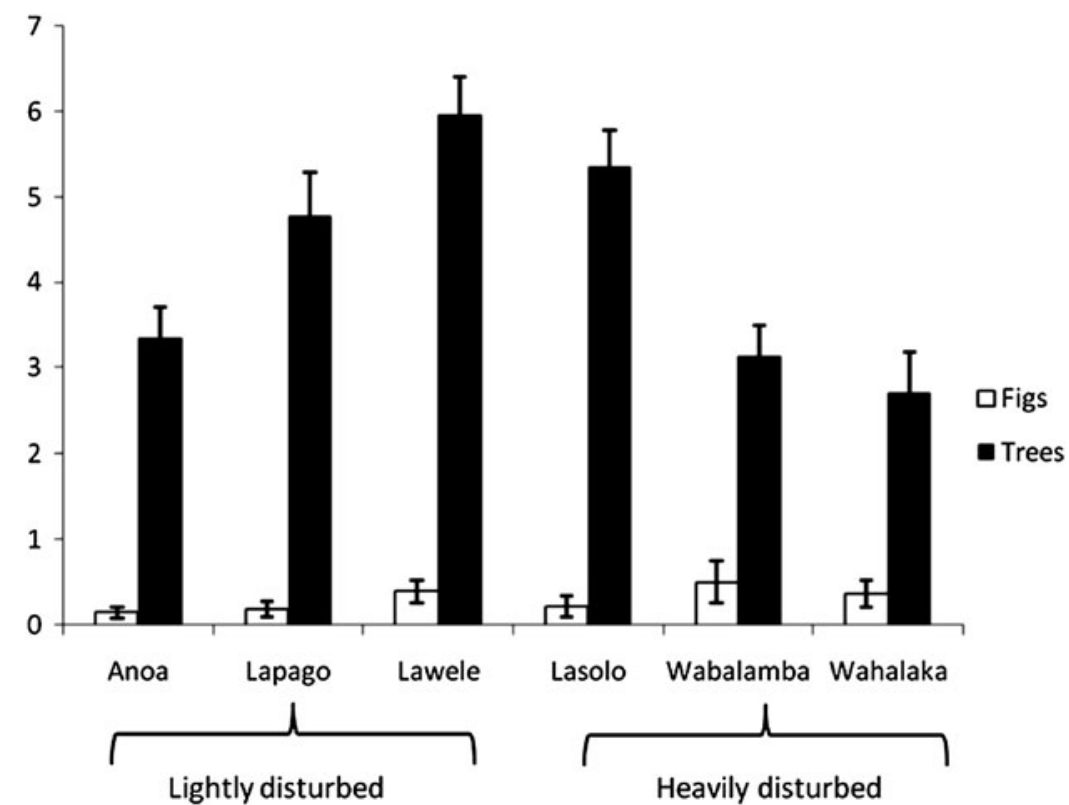

Figure 2. Distribution of figs and large trees $(\mathrm{DBH}>50 \mathrm{~cm})$ within study sites.

Sulawesi Tarictic Hornbills $(U=3454.0, Z=-0.24, P>0.05$. The Distance analysis fitted a uniform detection function and suggested that the Red-knobbed Hornbills were at significantly higher density in the lightly disturbed habitats but there was no difference for Sulawesi Tarictic Hornbills (-1.96 $<Z>1.96)$ (Table 2; Figure 4).

Table 2. Density estimations of Sulawesi Tarictic Hornbill and Red-knobbed Hornbill at different habitats and study sites within Lambusango forest.

\begin{tabular}{lll}
\hline & Red-knobbed Hornbill & Sulawesi Tarictic Hornbill \\
\hline Number of observations & 236 & 378 \\
Lightly disturbed habitats & 204 & 198 \\
Anoa & 27 & 40 \\
Lapago & 73 & 55 \\
Lawele & 104 & 103 \\
Heavily disturbed habitats & 32 & 180 \\
Lasolo & 10 & 54 \\
Wabalamba & 17 & 81 \\
Wahalaka & 5 & 45 \\
Density estimates (pooled) & $0.04 \mathrm{grp} / \mathrm{ha}$ & $0.04 \mathrm{grp} / \mathrm{ha}$ \\
Density - Lightly disturbed \pm SE & $0.07 \mathrm{grp} / \mathrm{ha} \pm 0.012$ & $0.04 \mathrm{grp} / \mathrm{ha} \pm 0.004$ \\
Density - Heavily disturbed \pm SE & $0.01 \mathrm{grp} / \mathrm{ha} \pm 0.003$ & $0.03 \mathrm{grp} / \mathrm{ha} \pm 0.004$ \\
Z test density estimates lightly & 4.65 & 1.49 \\
$\quad$ vs heavily disturbed & & \\
Density - Protected area & $0.04 \mathrm{grp} / \mathrm{ha} \pm 0.008$ & $0.03 \mathrm{grp} / \mathrm{ha} \pm 0.008$ \\
Density - Production forest & $0.04 \mathrm{grp} / \mathrm{ha} \pm 0.008$ & $0.04 \mathrm{grp} / \mathrm{ha} \pm 0.010$ \\
Z test density estimates protected & 0.91 & 0.05 \\
$\quad$ vs unprotected status & & \\
Naïve occupancy estimate & 0.2738 & 0.5178 \\
\hline
\end{tabular}




\section{Factors affecting forest habitat occupancy by hornbills}

The occupancy analysis created 15 models for each hornbill species with different combinations of the covariates (Tables 3 and 4). The naïve occupancy estimate for Red-knobbed Hornbill was 0.2738 and Sulawesi Tarictic Hornbill was 0.5179. For Red-knobbed Hornbill, the model with the disturbance level and forest status covariates is the most parsimonious, while the model with large trees was the one selected for Sulawesi Tarictic hornbills (Tables 3 and 4). In support of these results, when we summed the AIC weights of each covariate, disturbance levels $(99.8 \%)$ and forest status $(86.8 \%)$ appeared as the important predictorsfor Red-knobbed Hornbill occupancy (Table 5) and large trees $(76.3 \%)$ for Sulawesi Tarictic Hornbill. Figs were not good predictors of the presence of hornbills.

\section{Discussion}

\section{Abundance and occupancy preference of hornbills}

Hornbills are secondary cavity nesters and prefer live, tall, and large trees (Poonswad 1995, Kinnaird and O'Brien 2007). Hornbills may vary in their choice of habitat and may tolerate recently logged areas (Marsden 1999). The abundance of hornbills is known to be related to food availability and in some species is also negatively related to habitat disturbance due to lower availability of food resource (Anggraini et al. 200o). Habitat destruction such as logging or forest fire may reduce numbers of their preferred nesting trees (Cahill and Walker 2000, Sodhi et al. 2004). In this study, disturbance seemed to affect the availability of large trees rather than fig availability with the lightly disturbed habitat containing more potential nesting trees than the heavily disturbed habitats (see also Jones et al. 1995, Marsden and Pilgrim 2003).

Both Red-knobbed and Sulawesi Tarictic Hornbills were more abundant in the least disturbed forest although only Red-knobbed Hornbill was significantly so. Previous studies have suggested that both species are able to live in a variety of forest types from primary to more disturbed

Table 3. Model likelihood of Red-knobbed Hornbill occupancy using four covariates: disturbance (dist), forest status (status), number of large trees (trees), and number of figs (fig).

\begin{tabular}{|c|c|c|c|c|c|c|}
\hline Model & AIC & $\triangle \mathrm{AIC}$ & $w$ & $\begin{array}{l}\text { Model } \\
\text { Likelihood }\end{array}$ & $\mathrm{K}$ & $-2 \mathrm{~L}$ \\
\hline$\Psi($ dist + status $), \mathrm{p}()$. & 330.03 & o & 0.3716 & 1 & 4 & 322.03 \\
\hline$\Psi($ dist + status + trees $), \mathrm{p}()$. & 331.10 & 1.07 & 0.2176 & 0.5857 & 5 & 321.10 \\
\hline$\Psi($ dist + status + fig $), \mathrm{p}()$. & 331.60 & 1.57 & 0.1695 & 0.4561 & 5 & 321.60 \\
\hline$\Psi($ dist + status + tree + fig $), \mathrm{p}()$. & 332.52 & 2.49 & 0.1070 & 0.2879 & 6 & 320.52 \\
\hline$\Psi($ dist + trees $), \mathrm{p}()$. & 334.00 & 3.97 & 0.0511 & 0.1374 & 4 & 326.00 \\
\hline$\Psi($ dist $), \mathrm{p}()$. & $334 \cdot 56$ & 4.53 & 0.0386 & 0.1038 & 3 & 328.56 \\
\hline$\Psi($ dist + tree + fig $), p()$. & $335 \cdot 37$ & $5 \cdot 34$ & 0.0257 & 0.0693 & 5 & $325 \cdot 37$ \\
\hline$\Psi($ dist + fig $), \mathrm{p}()$. & 336.22 & 6.19 & 0.0168 & 0.0453 & 4 & 328.22 \\
\hline$\Psi($ status + trees $), \mathrm{p}()$. & 342.21 & 12.18 & 0.0008 & 0.0023 & 4 & 334.21 \\
\hline$\Psi($ status + tree + fig $), \mathrm{p}()$. & 343.08 & 13.05 & 0.0005 & 0.0015 & 5 & 333.08 \\
\hline$\Psi($ status $), \mathrm{p}()$. & 344.28 & 14.25 & 0.0003 & 0.0008 & 3 & 338.28 \\
\hline$\Psi($ status + fig), $\mathrm{p}()$. & $345 \cdot 50$ & 15.47 & 0.0002 & 0.0004 & 4 & $337 \cdot 50$ \\
\hline$\Psi($ trees $), \mathrm{p}()$. & 346.45 & 16.42 & 0.0001 & 0.0003 & 3 & 340.45 \\
\hline$\Psi($ tree + fig $), \mathrm{p}()$. & $347 \cdot 36$ & $17 \cdot 33$ & 0.0001 & 0.0002 & 4 & $339 \cdot 36$ \\
\hline$\Psi($ fig), $\mathrm{p}()$. & 351.92 & 21.89 & $\mathrm{o}$ & o & 3 & $345 \cdot 92$ \\
\hline
\end{tabular}

Notes: $\Psi$ is the probability a site is occupied by hornbill species and $\mathrm{p}$ is the probability of detecting hornbill in $j$ th survey where $\Psi(.) \mathrm{p}($.$) assumes that hornbills presence and detection probability are constant across sites,$ $\triangle \mathrm{AIC}$ is the difference in AIC values between each model with the low (best) model, $w$ is the AIC model weight, $\mathrm{K}$ is the number of parameters in the model, $-2 \mathrm{l}$ is twice the negative log-likelihood e. 
Table 4. Model likelihood of Sulawesi Tarictic Hornbill occupancy using four covariates: disturbance (dist), forest status (status), number of large trees (trees), and number of figs (fig).

\begin{tabular}{|c|c|c|c|c|c|c|}
\hline Model & AIC & $\triangle \mathrm{AIC}$ & $w$ & $\begin{array}{l}\text { Model } \\
\text { Likelihood }\end{array}$ & K & $-2 \mathrm{~L}$ \\
\hline$\Psi($ trees $), \mathrm{p}()$. & 504.07 & $\mathrm{O}$ & 0.2208 & 1 & 3 & 498.07 \\
\hline$\Psi($ status $), \mathrm{p}()$. & $505 \cdot 39$ & 1.32 & 0.1141 & 0.5169 & 3 & $499 \cdot 39$ \\
\hline$\Psi($ dist + trees $), \mathrm{p}()$. & 505.47 & 1.40 & 0.1096 & 0.4966 & 4 & $497 \cdot 47$ \\
\hline$\Psi($ status + tree + fig $), \mathrm{p}()$. & 505.50 & 1.43 & 0.1080 & 0.4892 & 5 & $495 \cdot 50$ \\
\hline$\Psi($ status + tree $), \mathrm{p}()$. & 505.57 & 1.50 & 0.1043 & 0.4724 & 4 & $497 \cdot 57$ \\
\hline$\Psi($ tree + fig $), \mathrm{p}()$. & 505.71 & 1.64 & 0.0972 & 0.4404 & 4 & $497 \cdot 71$ \\
\hline$\Psi($ dist + status $), \mathrm{p}()$. & 507.19 & 3.12 & 0.0464 & 0.2101 & 4 & 499.19 \\
\hline$\Psi($ dist + status + trees $), \mathrm{p}()$. & $507 \cdot 37$ & $3 \cdot 30$ & 0.0424 & 0.192 & 5 & $497 \cdot 37$ \\
\hline$\Psi($ status + fig), $\mathrm{p}()$. & $507 \cdot 38$ & $3 \cdot 31$ & 0.0422 & 0.1911 & 4 & $499 \cdot 38$ \\
\hline$\Psi($ dist + tree + fig $), \mathrm{p}()$. & $507 \cdot 46$ & $3 \cdot 39$ & 0.0405 & 0.1836 & 5 & $497 \cdot 46$ \\
\hline$\Psi($ dist + status + tree + fig $), \mathrm{p}()$. & $507 \cdot 49$ & $3 \cdot 42$ & 0.0399 & 0.1809 & 6 & $495 \cdot 49$ \\
\hline$\Psi($ dist + status + fig $), \mathrm{p}()$. & 509.08 & 5.01 & 0.018 & 0.0817 & 5 & 499.08 \\
\hline$\Psi$ (fig), $\mathrm{p}()$. & 510.99 & 6.92 & 0.0069 & 0.0314 & 3 & 504.99 \\
\hline$\Psi($ dist $), \mathrm{p}()$. & 511.00 & 6.93 & 0.0069 & 0.0313 & 3 & 505.00 \\
\hline$\Psi($ dist + fig $), \mathrm{p}()$. & 512.90 & 8.83 & 0.0027 & 0.0121 & 4 & 504.90 \\
\hline
\end{tabular}

See notes under Table 3 for explanation of symbols

habitats but exist in the latter if there is still a high proportion of native forest cover (Waltert et al. 2004, Sodhi et al. 2004). Waltert et al. (2004) found that Red-knobbed Hornbill was absent in secondary forest and agro-forest area while Sodhi et al. (2004) found both absent in plantations. Alvard and Winarni (1999) indicated that Red-knobbed Hornbills were more common in a forest close to horticultural activities, although soil differences might also play a role - they were absent in forest on ultrabasic soils while Sulawesi Tarictic Hornbill occurred in forests on both ultrabasic and limestone soils.

The ability to survive in disturbed habitats varies between hornbill species (Datta 1998, Kinnaird and $\mathrm{O}^{\prime}$ Brien 2007) and in this case the effect of disturbance was more noticeable in Redknobbed Hornbill than in Sulawesi Tarictic Hornbill. Red-knobbed Hornbill showed a preference for the less disturbed habitats and this was reflected in its densities, presence at individual stations, and its habitat occupancy. Research has shown that abundance and distribution of the wide-ranging Red-knobbed Hornbill is resource-limited, particularly by figs, and their presence and movement is related to their search for figs (Kinnaird et al. 1996, Kinnaird and O'Brien 2005; Hadiprakarsa et al. 2007). In Lambusango, however, the Red-knobbed Hornbill seemed to be affected more by the availability of potential nesting trees rather than the density of figs. There is also the possibility that the phenology of the figs may be more important than their presence alone.

Occupancy was less predictable for Sulawesi Tarictic Hornbill and its presence does not seem to be strongly correlated with the level of disturbance. This is a small-bodied, cooperatively breeding hornbill with a small home range which appears to be reluctant to move to new, unknown patches (Meijaard et al. 2005, Kinnaird and O'Brien 2007). Small hornbills also tend to have wider diets and are able to rely on fruit resources within territories (O'Brien 1997, Hadiprakarsa et al. 2007,

Table 5. Sum weights of AIC for each covariate to explain the importance for hornbill occupancy.

\begin{tabular}{lll}
\hline Covariates & Red-knobbed Hornbill & Sulawesi Tarictic Hornbill \\
\hline Disturbance & 0.998 & 0.306 \\
Forest status & 0.868 & 0.515 \\
Large trees & 0.403 & 0.763 \\
Figs & 0.320 & 0.355 \\
\hline
\end{tabular}


Kinnaird and O'Brien 2007). The pattern of occupancy by Sulawesi Tarictic Hornbills in Lambusango appears to be influenced by the presence of large trees but further research is required to determine whether this is typical throughout its range. Large trees are required for nesting (Poonswad 1995, Kinnaird and O'Brien 2007) and it is the larger trees within the high canopy which may produce the larger fruit crops (Johns 1987, Kinnaird and O'Brien 2007).

Although forest status was an important predictor of habitat occupancy by Red-knobbed Hornbill, protection status did not figure in the occupancy analysis and was not related to disturbance. In Indonesia, many of the protected areas are not secure from deforestation (Curran et al. 2004, Linkie et al. 2004, Gaveau et al. 2007). In Sulawesi, <20\% optimal habitat for Redknobbed and Sulawesi Tarictic Hornbills is within protected areas (Kinnaird and O'Brien 2007). However, the protected status may still effectively decelerate deforestation particularly from large-scale mechanised logging operations (Gaveau et al. 2007). A 2004 spatial analysis of Lambusango (Coles 2006) demonstrated that although most of the forest was still in a reasonable condition, even within protected areas there was still considerable rattan extraction and there is no guarantee that protected status is able to prevent forest loss (see also Curran et al. 2004).

\section{Conservation priorities for Lambusango}

Forest in Lambusango has suffered damage as a result of a variety of anthropogenic activities and these may have affected hornbill populations and particularly that of the Red-knobbed Hornbill. The Lambusango forest is now a habitat island, human settlement continues and is creating a modified habitat matrix which makes the forest even more isolated. Although species such as Red-knobbed Hornbill can be considered as 'landscape species' (Sanderson et al. 2002, Kinnaird and O'Brien 2007) because of the ability to move long distances between forest patches, they still need areas with lower levels of disturbance. The lightly disturbed areas within Lambusango may provide the essential areas in which the large trees provide nest sites. Areas such as Anoa, Lawele, and Lapago which are currently considered lightly disturbed, were still accessible and prone to anthropogenic activities, and therefore need particular attention from site managers. It is probably valid to pay particular attention to the needs of the hornbills as they can act as umbrella species for other elements of forest biodiversity (Lambeck 1997, Caro and O'Doherty 1999). Their sensitivity to disturbance also makes them good indicators of habitat quality and habitat change (Caro and O'Doherty 1999).

\section{Acknowledgements}

This project was part of Bird Monitoring - Lambusango Forest Conservation Programme of the Global Environmental Facility and the Operation Wallacea Trust. We thank Drs. Tim Coles and Edi Purwanto for supporting us through the project as well as the Head of Balai Konservasi Sumber Daya Alam (BKSDA) Sulawesi Tenggara for giving us permission to work in the Lambusago reserves. We also thank our field assistants, students and volunteers of the Operation Wallacea, as well as people of Labundo-bundo in Buton. This paper derives from the $5^{\text {th }}$ International Hornbill Conference held at the National Parks Board, Singapore on 22-25 March 2009 .

\section{References}

Alvard, M. S. and Winarni, N. L. (1999) Avian biodiversity in Morowali Nature Reserve, Central Sulawesi, Indonesia and the impact of human subsistence activities. Tropical Biodivers. 6: 59-74.
Anggraini, K., Kinnaird, M. and $\mathrm{O}^{\prime}$ Brien, $\mathrm{T}$. (2000) The effects of fruit availability and habitat disturbance on an assemblage of Sumatran hornbills. Bird Conserv. Int. 10: 189-202. 
Buckland, S. T., Anderson, D. R., Burnham, K. P., Laake, J. L., Borchers, D. L. and Thomas, L. (2001) Introduction to distance sampling: estimating abundance of biological populations. Oxford: Oxford University Press.

Burnham, K. P. and Anderson, D. R. (2004) Multimodel inference: Understanding AIC and BIC in model selection. Sociol. Method. Res. 33: 261-304.

Cahill, A. J. and Walker, J. S. (2000) The effects of forest fire on the nesting success of the Red-knobbed Hornbill Aceros cassidix. Bird Conserv. Int. 10: 109-114.

Caro, T. M. and O'Doherty, G. (1999) On the use of surrogate species in conservation biology. Conserv. Biol.13: 805-814.

Cleary, D. F. R., Boyle, T. J. B., Setyawati, T., Anggraeni, C. D., Loon, E. E. V. and Menken, S. B. J. (2007) Bird species and traits associated with logged and unlogged forest in Borneo. Ecol. Applic. 17: 11841197.

Coates, B., Bishop, K. D. and Gardner, D. (1997) A guide to the birds of Wallacea: Sulawesi, the Moluccas and Lesser Sunda Islands, Indonesia. Alderley, Queensland: Dove Publications.

Coles, T. (2006) State of the Lambusango forests 2006. Bau-bau, Indonesia: Operation Wallacea Trust.

Curran, L. M., Trigg, S. N., McDonald, A. K., Astiani, D., Hardiono, Y. M., Siregar, P., Caniago, I. and Kasischke, E. (2004) Lowland forest loss in protected areas of Indonesian Borneo. Science 303: 1000-1003.

Datta, A. (1998) Hornbill abundance in unlogged forest, selectively logged forest and a forest plantation in Arunachal Pradesh, India. Oryx 32: 285-294.

FWI/GFW (2002) The state of the forest: Indonesia. Bogor, Indonesia and Washington, DC: Forest Watch Indonesia and Global Forest Watch.

Gaveau, D. L. A., Wandono, H. and Setiabudi, F. (2007) Three decades of deforestation in southwest Sumatra: Have protected areas halted forest loss and logging, and promoted re-growth? Biol. Conserv. 134: 495-504.
Hadiprakarsa, Y. (2008) Forest patch occupancy by Sumatran hornbills in a fragmented landscape of southern Sumatra, Indonesia. Masters Thesis. Graduate School, University of Georgia, Athens.

Hadiprakarsa, Y., Kinnaird, M. F., Iqbal, M. and $\mathrm{O}^{\prime}$ Brien, T. G. (2007) Forest fragmentation effects on hornbills across the southern Sumatra landscape. Pp. 80-9I in A. C. Kemp and M. I. Kemp, eds. The active management of hornbills and their habitats for conservation. Proceedings of the $4^{\text {th }}$ International Hornbill Conference, Belabela, South Africa: Mabula Game Lodge.

Holmes, D. A. (2002) Indonesia: Where have all the forests gone? Washington DC: The World Bank.

Johns, A. D. (1987) The use of primary and selectively logged rainforest by Malaysian hornbills (Bucerotidae) and implications for their conservation. Biol. Conserv. 40: 179190.

Jones, M. J., Linsley, M. D. and Marsden, S. J. (1995) Population sizes, status and habitat associations of the restricted-range bird species of Sumba, Indonesia. Bird Conserv. Int. 5: 21-52.

Kalina, J. (1988) Ecology and behavior of the Black-and-White Casqued Hornbill (Bycanistes subcylindricus subquadratus) in Kibale Forest, Uganda. PhD Dissertation. Michigan State University, Michigan.

Kinnaird, M. F. and O'Brien, T. G. (2005) Fast foods of the forest: The influence of figs on primates and hornbills across Wallace's line. Pages 155-184in J. L. Dew and J. P. Boubli, eds. Tropical fruits and frugivores: the search for strong interactors. New York: Springer.

Kinnaird, M. F. and O'Brien, T. G. (2007) The ecology and conservation of Asian hornbills: Farmers of the forest. Chicago and London: The University of Chicago Press.

Kinnaird, M. F., O'Brien, T. G. and Suryadi, S. (1996) Population fluctuation in Sulawesi red-knobbed hornbills: tracking figs in space and time. The Auk 113: 431-440.

Lambeck, R. J. (1997) Focal species: A multispecies umbrella for nature conservation. Conserv. Biol. 11: 849-856. 
Lee, D. C. and Marsden, S. J. (2008) Adjusting count period strategies to improve the accuracy of forest bird abundance estimates from point transect distance sampling surveys. Ibis 150: 315-325.

Linkie, M., Smith, R. J. and Leader-Williams, N. (2004) Mapping and predicting deforestation patterns in the lowlands of Sumatra. Biodivers. Conserv. 13: 1809-1818.

MacKenzie, D. I., Nichols, J. D., Lachman, G. B., Droege, S., Royle, A. J. and Langtimm, C. A. (2002) Estimating site occupancy rates when detection probabilities are less than one. Ecology 83: 2248-2255.

MacKenzie, D. I., Nichols, J. D., Royle, A. J., Pollock, K. H., Bailey, L. L. and Hines, J. E. (2006) Occupancy estimation and modeling: Inferring patterns and dynamics of species occurrence. Amsterdam: Elsevier.

Marsden, S. J. (1999) Estimation of parrot and hornbill densities using a point count distance sampling method. Ibis 141: 327-390.

Marsden, S. J. and Jones, M. J. (1997) The nesting requirements of the parrots and hornbill of Sumba, Indonesia. Biol. Conserv. 82: 279-287

Marsden, S. J. and Pilgrim, J. D. (2003) Factors influencing the abundance of parrots and hornbills in pristine and disturbed forests on New Britain, Papua New Guinea. Ibis 145: 45-53.

Marsden, S. J., Whiffin, M. and Galetti, M. (2001) Bird diversity and abundance in forest fragments and Eucalyptus plantations around an Atlantic forest reserve, Brazil. Biodivers. Conserv. 10: 737751 .

Meijaard, E., Sheil, D., Nasi, R., Augeri, D., Rosenbaum, B., Iskandar, D., Setyawati, T., Lammertink, M., Rachmatika, I., Wong, A., Soehartono, T., Stanley, S. and O'Brien, T. G. (2005) Life after logging: reconciling wildlife conservation and production forestry in Indonesian Borneo. Bogor, Indonesia: CIFOR.

O'Brien, T. G. (1997) Behavioural ecology of the North Sulawesi Tarictic Hornbill Penelopides exarhatus exarhatus during the breeding season. Ibis 139: 97-101.

O'Brien, T. G. and Kinnaird, M. F. (200o) Differential vulnerability of large birds and mammals to hunting in North Sulawesi,
Indonesia, and the outlook for the future. Pages 199-213 in E. L. Bennett and J. G. Robinson. eds. Hunting for sustainability in tropical forests. New York: Columbia University Press.

Poonswad, P. (1995) Nest site characteristics of four sympatric species of hornbills in Khao Yai National Park, Thailand. Ibis 137: 183-191.

Reynolds, R. T., Scott, J. M. and Nussbaum, R. A. (1980) A variable circular-plot method for estimating bird numbers. Condor 82: 309-313.

Sanderson, E. W., Redford, K. H., Vedder, A., Coppolillo, P. B. and Ward, S. E. (2002) A conceptual model for conservation planning based on landscape species requirements. Landscape Urban Plan. 58: 41-56.

Seymour, A. (2004) Monitoring forest degradation and animal populations in the forests of Central Buton: preliminary results from the pilot study. Bau-Bau, Indonesia: Operation Wallacea Trust.

Singer, H. A. and Purwanto, E. (2006) MisterikekayaanhayatihutanLambusango. Program KonservasiHutanLambusango (PKHL). Bau-bau, Indonesia: Operation Wallacea Trust.

Sodhi, N. S., Liow, L. H. and Bazzaz, F. A. (2004) Avian extinctions from tropical and subtropical forests. Annu. Rev. Ecol. Evol. Syst. 35: 323-345.

Thomas, L., Laake, J. L., Strindberg, S., Marques, F. F. C., Buckland, S. T., Borchers, D. L., Anderson, D. R., Burnham, K. P., Hedley, S. L., Pollard, J. H., Bishop, J. R. B. and Marques, T. A. (2006) Distance 5.o. Release 2. St Andrews, UK: Research Unit for Wildlife Population Assessment, University of St. Andrews.

Walker, J. S. (2007) Dietary specialization and fruit availability among frugivorous birds on Sulawesi. Ibis 149: 345-356.

Waltert, M., Mardiastuti, A. and Muhlenberg, M. (2004) Effects of land use on bird species richness in Sulawesi, Indonesia. Conserv. Biol. 18: 1339-1346.

Whitney, K. D. and Smith, T. B. (1998) Habitat use and resource tracking by African Ceratogymna hornbills: implications for seed dispersal and forest conservation. Anim. Conserv. 1: 107-117. 
Whitten, A. J., Henderson, G. S. and Mustafa, M. (2002) The ecology of Sulawesi. Hong Kong: Periplus Edition (HK) Ltd.

Winarni, N. L. (2009) Community patterns of birds and butterflies in tropical forest of southeast Sulawesi and the selection of indicator species for ecological monitoring. PhD Thesis. School of Biology, Chemistry and Health Science.
Faculty of Science and Engineering. Manchester Metropolitan University, Manchester, UK.

Winarni, N. L. and Jones, M. J. (2009) The effect of anthropogenic disturbance on hornbill populations in Buton, southeast Sulawesi. 63 pp. $5^{\text {th International Hornbill }}$ Conference, Singapore Botanic Gardens, Singapore.

\section{NURUL L. WINARNI*, MARTIN JONES}

Division of Biology and Conservation Ecology, Faculty of Science and Engineering, Manchester Metropolitan University, John Dalton Building, Chester Street, Manchester M1 5GD, United Kingdom.

*Author for correspondence; e-mail:nl_winarni@yahoo.com

Received 14 March 2010; revision accepted 28 March 2011;

Published online 27 May 2011 